\title{
PENERAPAN TEKNOLOGI PAKAN DAN LIMBAH TERNAK UNTUK PEMBERDAYAAN KELOMPOK TANI DESA OEBELO, KABUPATEN KUPANG
}

\section{APPLICATION OF FEED TECHNOLOGY AND LIVESTOCK WASTE FOR FARMER GROUP EMPOWERMENT IN OEBELO VILLAGE, KUPANG REGENCY}

\author{
Melkianus Dedimus Same Randu ${ }^{1)^{*}}$, Lenny Marlina Mooy ${ }^{2)}$, Ferdinan Suharjono Suek ${ }^{3)}$, \\ I Gusti Komang Oka Wirawan ${ }^{4}$ \\ ${ }^{1)}$ Jurusan Peternakan, Politeknik Pertanian Negeri Kupang. email: deddy_randu@yahoo.co.id \\ ${ }^{2)}$ Jurusan Tanaman Pangan dan Hortikultura, Politeknik Pertanian Negeri Kupang \\ email: mooy_ch@yahoo.co.id \\ ${ }^{3)}$ Jurusan Peternakan, Politeknik Pertanian Negeri Kupang. email: ferdi.suek@ gmail.com \\ 4)Jurusan Peternakan, Politeknik Pertanian Negeri Kupang. email: oka_sayun@yahoo.com
}

\section{ABSTRAK}

Desa Oebelo memiliki prospek untuk pengembangan peternakan sapi potong. Namun demikian, kontribusi pengelolaan limbah pertanian masih perlu ditingkatkan akibat kurangnya pengetahuan tentang pengolahan limbah batang dan daun jagung serta feses ternak sapi. Kegiatan pengabdian bertujuan meningkatkan pengetahuan, sikap, dan keterampilan dalam mengolah limbah pertanian sehingga dapat mendukung pengembangan sistem usaha tani terpadu di Desa Oebelo. Kegiatan pengabdian kepada masyarakat melibatkan kelompok tani ternak Syalom dan Elsadai. Metode pelaksanaan kegiatan pengabdian meliputi penyuluhan, demonstrasi plot pembuatan silase dan bokashi pupuk kandang, serta evaluasi dan pendampingan. Luaran yang dihasilkan meliputi produk silase lamtoro sebanyak $250 \mathrm{~kg}$, silase jerami jagung sebanyak $450 \mathrm{~kg}$, bokashi pupuk kandang sebanyak $1.200 \mathrm{~kg}$, dan pendapatan mitra per proses produksi sebesar Rp.850.000,-. Kegiatan pengabdian memberikan manfaat dalam penguasaan teknologi pembuatan silase dan bokashi pupuk kandang. Anggota mitra kelompok tani juga membangun komitmen untuk menerapkan pengetahuan yang diperoleh dengan terus mengolah limbah pertanian sehingga dapat memberikan nilai tambah dan meningkatkan kualitas lingkungan.

Kata kunci: Bokashi, Desa Oebelo, Fermentasi, Lingkungan, Silase

\section{ABSTRACT}

The village of Oebelo has prospect in beef cattle farming development; nevertheless, farming waste management to contribute a value-added is still required to be improved due to the lack of knowledge on cultivating corn stalk and leaves waste as well as cattle feces. The empowerment program aims to improve knowledge, attitude, and skill among the farmers on cultivating farming waste to development of integrated beef cattle farming activities in Oebelo. The program has been involving Syalom and Elsadai farmer groups. The methods that had been practiced in the field project were extension, practice, and simulation of silage technique and bokashi organic fertilizer, evaluation and mentorship. The result of the program including silage products of plant type as follows: Lamtoro plant (Leucaena leucocephala) silage as $250 \mathrm{Kg}$ and corn stalk silage as $450 \mathrm{Kg}$, and bokashi organic fertilizer as 1,200 Kg. During each of the production phases, villagers who involved in this program earned 850,000 rupiahs. The empowerment program has given an impacttransfer technology of silage and bokashi organic fertilizer. Post-project, all beef cattle farmers have been establishing a joint commitment to implement the knowledge they gain and keep cultivating farming waste to give value-added and improving the quality of the environment.

Keywords: Bokashi, Oebelo Village, Fermentation, Environment, Silage

\section{PENDAHULUAN}

Oebelo merupakan salah satu desa di
Kupang, Provinsi Nusa Tenggara Timur

(NTT) dengan jarak $\pm 18 \mathrm{~km}$ dari ibu Kota

Kecamatan Kupang Tengah, Kabupaten Kabupaten Kupang. Luas wilayah Desa 
Oebelo adalah $9,76 \mathrm{~km}^{2}$, dan dominasi pencaharian penduduk bersumber di sektor pertanian (95\%). Komoditas pertanian dan peternakan yang dibudidayakan meliputi padi sawah, padi ladang, jagung, tomat, cabe, kangkung, ternak sapi, kambing, babi, dan unggas [1].

Syalom dan Elsadai merupakan mitra kelompok tani ternak yang berada di RT 01/RW01 dan RT 05/RW03 Desa Oebelo. Kelompok mitra tersebut secara formal terbentuk tahun 2009. Aktifitas kelompok mitra dalam bidang pertanian dan peternakan telah dijalankan secara periodik walaupun hanya mengandalkan lahan garapan sebagai sumber pendapatan rumah tangga. Pada lahan yang tidak dialiri air, dilakukan budidaya padi ladang, jagung, dan sayursayuran, sedangkan lahan yang dialiri air dimanfaatkan untuk budidaya padi sawah. Pemeliharaan ternak sapi dan kambing dilakukan oleh anggota kelompok mitra melalui sistem pemeliharaan semi intensif.

Anggota mitra dalam menjalankan usaha budidaya tanaman jagung umumnya selalu membiarkan limbah sisa hasil panen (batang dan daun jagung) mengering kemudian dibakar, sehingga diharapkan dapat meningkatkan unsur hara tanah serta mengurangi kemungkinan munculnya hama penyakit. Kondisi tersebut mengakibatkan tidak adanya pemanfaatan limbah jagung sebagai pakan ternak sapi dan kambing. Kegiatan membakar limbah pertanian baik jerami padi maupun jerami jagung merupakan kebiasaan yang sering dilakukan oleh para petani peternak di wilayah Kabupaten Kupang [2].

Kebutuhan pakan bagi ternak yang dipelihara oleh anggota mitra umumnya bersumber dari hijauan Gamal (Gliricidiasepium) dan Lamtoro (Leucaena leucocephala) dengan jumlah maupun ketersediaan yang bervariasi berdasarkan musim. Pada musim hujan, ketersediaan hijauan sangat melimpah, sebaliknya di musim kemarau sangat terbatas. Walaupun demikian, hijauan lamtoro lebih disukai oleh ternak sapi dan kambing dibandingkan gamal. Demikian pula, feses yang dihasilkan dari pemeliharaan ternak sapi dan kambing tidak pernah diolah sebagai pupuk organik.

Berdasarkan observasi dan diskusi bersama anggota kelompok mitra, diketahui permasalahan prioritas yang perlu mendapatkan penanganan, antara lain: tidak adanya pemanfaatan limbah tanaman jagung sebagai sumber pakan alternatif bagi ternak sapi dan kambing, tidak dilakukannya pengolahan hijauan yang berkelimpahan di musim hujan untuk dimanfaatkan secara berkelanjutan pada musim kemarau, serta belum diketahuinya upaya untuk mengolah limbah peternakan (feses) menjadi pupuk organik (bokashi).

Solusi yang dilakukan untuk mengatasi permasalahan prioritas di tingkat kelompok mitra adalah membuat silase menggunakan bahan baku lamtoro dan jerami jagung. Menurut [3] silase adalah hijauan makanan ternak yang disimpan dalam keadaan segar pada sebuah silo, bersifat anaerob, dan mengalami proses fermentasi selama 
beberapa waktu sehingga menjadi awet. menggunakan lamtoro dan limbah jagung, Silase dimanfaatkan untuk mengatasi serta teknologi limbah (bokashi) kekurangan pakan pada musim kemarau. menggunakan bahan baku pupuk kandang.

Solusi lainnya adalah membuat bokashi pupuk kandang dengan memanfaatkan feses sapi. [4], [5], [6] menyatakan bahwa bokashi merupakan pupuk kompos yang dihasilkan melalui proses fermentasi bahan organik menggunakan teknologi EM4 (effective Microorganism). Keberadaan bokashi diharapkan mampu menggantikan penggunaan pupuk kimia (anorganik) untuk meningkatkan kesuburan tanah, memperbaiki kerusakan fisik, kimia maupun biologi tanah.

Kegiatan pengabdian yang dilaksanakan bertujuan meningkatkan pengetahuan dan keterampilan anggota mitra dalam menerapkan teknologi pengolahan pakan menggunakan bahan baku lokal, mengolah limbah peternakan menjadi produk yang bermanfaat bagi tanaman, meningkatkan kontribusi ekonomi rumah tangga, mengembangkan sistem usaha tani terintegrasi, dan meningkatkan kualitas lingkungan sebagai dampak dari penerapan sistem pertanian ramah lingkungan.

\section{METODE PELAKSANAAN KEGIATAN}

Kegiatan pengabdian dilaksanakan di Desa Oebelo, Kecamatan Kupang Tengah, Kabupaten Kupang, Provinsi NTT selama 6 bulan. Kegiatan tersebut diikuti oleh 17 orang anggota kelompok tani Syalom dan Elsadai. Secara teknis, pelaksanaan kegiatan pengabdian dilakukan menggunakan metode pendidikan masyarakat berupa in-house training dan penyuluhan, serta substitusi ipteks melalui introduksi teknologi silase
Bahan utama yang digunakan untuk membuat silase adalah daun lamtoro, jerami jagung, dan dedak halus, sedangkan peralatan utama yang digunakan adalah pencacah (parang dan mesin chooper), silo (ember plastik 60 liter dan bak penampung), plastik penutup, dan karet ban pengikat. Selanjutnya bahan utama yang digunakan dalam membuat bokashi pupuk kandang meliputi feses sapi kering, dedak padi, arang sekam, air, gula pasir, dan EM-4, sedangkan peralatan utama yang digunakan adalah ember, kawat ayakan/saringan, sekop, karung, dan terpal.

Metode pelaksanaan kegiatan pengabdian difokuskan secara aktif kepada anggota mitra melalui pendekatan pendidikan orang dewasa (andragogi). Pelaksanaan kegiatan secara teknis dirancang menggunakan metode penyuluhan, demonstrasi plot (demplot), evaluasi dan pendampingan. Uraian masing-masing metode pelaksanaan, sebagai berikut:

\section{1) Penyuluhan}

Kegiatan tersebut dilakukan untuk meningkatkan pengetahuan anggota mitra tentang manfaat pakan bagi ternak, teknologi pengolahan pakan, strategi menyediakan pakan sepanjang tahun dengan memanfaatkan bahan baku hijauan maupun limbah pertanian, serta pengolahan limbah peternakan (feses) yang tersedia di sekitar wilayah anggota mitra. Untuk memudahkan pemahaman, anggota mitra diberikan materi 
dalam bentuk leaflet. Materi penyuluhan yang diberikan dalam kegiatan dapat dilihat pada Tabel 1.

Tabel 1. Materi Kegiatan Pengabdian

\begin{tabular}{cl}
\hline No & \multicolumn{1}{c}{ Materi } \\
\hline 1. & Pengenalan teknologi pakan \\
\hline 2. & $\begin{array}{l}\text { Strategi penyediaan pakan } \\
\text { berkelanjutan }\end{array}$ \\
\hline 3. & $\begin{array}{l}\text { Teknologi pembuatan silase } \\
\text { sebagai pakan ternak ruminansia } \\
\text { (sapi potong dan Kambing) }\end{array}$ \\
\hline 4. & $\begin{array}{l}\text { Teknologi pembuatan bokashi pupuk } \\
\text { kandang }\end{array}$ \\
\hline
\end{tabular}

\section{2) Demonstrasi Plot (Demplot)}

Kegiatan demplot ditujukan untuk meningkatkan keterampilan anggota mitra kelompok tani ternak Syalom dan Elsadai dalam menerapkan teknologi pengolahan pakan dan limbah ternak menjadi produk yang dapat bermanfaat serta digunakan dalam aktivitas usaha pertanian maupun peternakan. Dalam pelaksanaannya, anggota mitra bersama tim pelaksana pengabdian mempersiapkan alat dan bahan yang dibutuhkan, kemudian dilakukan penjelasan singkat tentang materi demplot yang dibuat, dan selanjutnya secara bersama-sama melakukan pembuatan silase lamtoro dan silase jerami jagung, serta bokashi pupuk kandang sesuai petunjuk teknis pelaksanaan (Gambar 2, 3, dan 4).

\section{3) Evaluasi dan Pendampingan}

Kegiatan evaluasi dan pendampingan ditujukan untuk mengetahui apakah teknologi yang diimplementasikan dapat diterapkan secara optimal oleh anggota mitra kelompok tani ternak. Evaluasi dilakukan bersama anggota mitra untuk menilai kualitas fisik silase dan bokashi pupuk kandang.
Pendampingan dilakukan untuk terus memantau pembuatan silase dan bokashi pupuk kandang secara mandiri oleh anggota mitra, termasuk sistem pemasaran dan analisis ekonomi. Hal tersebut merupakan sesuatu yang sangat penting sebagai suatu kesatuan produksi terutama untuk melihat sejauh mana pemberdayaan anggota mitra dapat dilakukan.

\section{HASIL DAN PEMBAHASAN}

\section{Kegiatan Penyuluhan}

Pelaksanaan pengabdian yang dilakukan di kelompok tani ternak Syalom dan Elsadai didahului oleh kegiatan penyuluhan. Kegiatan tersebut diikuti 17 orang anggota mitra yang terdiri dari 8 orang anggota kelompok tani ternak Syalom dan 9 orang anggota kelompok tani ternak Elsadai. Kegiatan penyuluhan didampingi oleh 3 orang mahasiswa dari Politeknik Pertanian Negeri Kupang. Narasumber kegiatan penyuluhan adalah tim pelaksana pengabdian yang memiliki kompetensi ilmu sesuai permasalahan yang dialami anggota mitra. Kegiatan penyuluhan telah dilaksanakan dengan baik, dibuktikan dari semangat anggota mitra kelompok tani untuk mengikuti kegiatan penyuluhan, mengajukan pertanyaan, serta membangun diskusi seputar permasalahan yang dihadapi. Kegiatan penyuluhan yang dilakukan dapat dilihat pada Gambar 1.

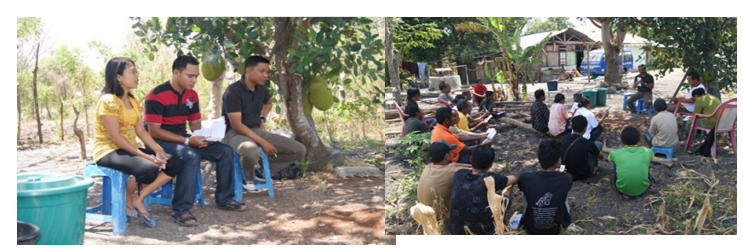

Gambar 1. Dokumentasi penyuluhan 


\section{Kegiatan Demonstrasi Plot}

Demonstrasi plot (Demplot) pembuatan silase lamtoro telah meningkatkan pengetahuan dan keterampilan anggota mitra kelompok tani ternak Syalom dan Elsadai dalam mengetahui manfaat silase untuk mendukung ketersediaan pakan dan usaha peternakan, membedakan ciri fisik silase yang baik, menumbuhkan kesadaran untuk mengelola kelebihan pakan di musim hujan sehingga dapat dimanfaatkan pada musim kemarau, serta merencanakan pembuatan silase lanjutan menggunakan limbah tanaman jagung. Melalui demplot diketahui mitra memahami pentingnya strategi penyediaan pakan secara berkelanjutan. Indikator pembuatan silase lamtoro terlihat dari produksi sebesar $\pm 250 \mathrm{~kg}$. Pembuatan silase lamtoro dapat dilihat pada Gambar 2.
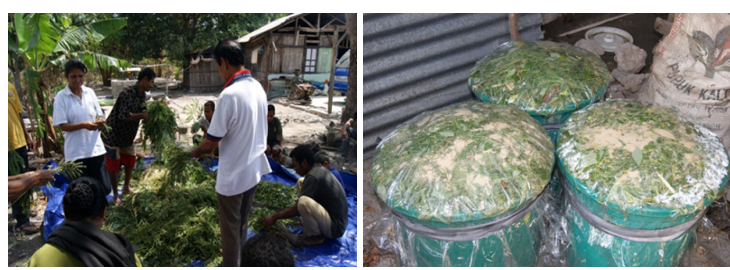

Gambar 2. Demplot pembuatan silase lamtoro

Demplot pembuatan bokashi pupuk kandang yang dilakukan berhasil mengedukasi anggota mitra tentang manfaat ekonomis bokashi pupuk kandang. Kegiatan demplot juga meningkatkan keterampilan membuat bokashi menggunakan feses sapi. Hasil akhir yang diharapkan dari kegiatan demplot di masa mendatang adalah penerapan teknologi berbasis organik yang dapat dimanfaatkan oleh anggota mitra. Kegiatan demplot berhasil memproduksi bokashi pupuk kandang sebanyak $\pm 1200 \mathrm{~kg}$ dalam beberapa periode kegiatan. Anggota mitra juga telah menjual produk bokashi pupuk kandang sehingga memperoleh pendapatan sebesar sebesar Rp. 850.000,-. Pembuatan bokashi pupuk kandang dapat dilihat pada Gambar 3.

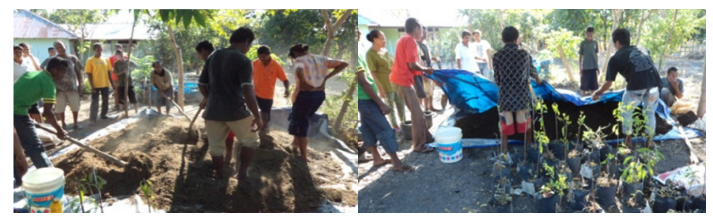

Gambar 3. Demplot pembuatan bokashi

\section{Kegiatan Monitoring dan Evaluasi}

Hasil monitoring dan evaluasi menunjukkan tingginya partisipasi (90\%) anggota mitra kelompok tani melalui kebersamaan mempersiapkan bahan baku, serta memperhatikan secara aktif setiap proses pembuatan silase lamtoro dan bokashi pupuk kandang seperti teknik pemadatan silase maupun pencampuran atau pembalikan bokashi. Partisipasi dan rasa ingin tahu lainnya diwujudkan oleh anggota mitra melalui pembuatan silase secara mandiri dengan menggunakan bahan baku jerami jagung sebanyak $\pm 450 \mathrm{~kg}$ dan disimpan di dalam bak penampung. Pembuatan silase menggunakan bahan baku jerami jagung dapat dilihat pada Gambar 4.

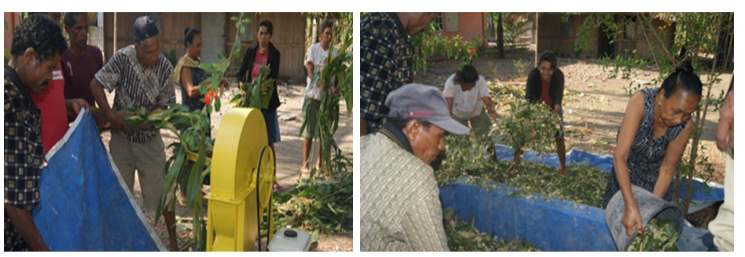

Gambar 4. Demplot pembuatan silase jagung

\section{KESIMPULAN}

Berdasarkan serangkaian hasil yang telah dilaksanakan, dapat disimpulkan bahwa kegiatan pengabdian kepada masyarakat telah memberikan hasil dan manfaat positif 
bagi anggota mitra kelompok tani ternak Syalom dan Elsadai. Hal tersebut dicerminkan dari tingginya partisipasi dalam mengikuti penyuluhan dan demonstrasi plot, meningkatnya pengetahuan dan keterampilan anggota mitra dalam melakukan pembuatan silase lamtoro, silase jerami jagung, serta pembuatan bokashi menggunakan bahan baku dasar pupuk kandang.

Manfaat lainnya yang juga diperoleh dari kegiatan pengabdian masyarakat adalah anggota mitra kelompok tani Syalom dan Elsadai mampu menerapkan teknologi pembuatan silase dan bokashi pupuk kandang secara mandiri. Hal tersebut diketahui dari adanya pendapatan yang diperoleh dari penjualan bokashi pupuk kandang, serta keinginan bersama anggota mitra kelompok tani Syalom dan Elsadai di Desa Oebelo untuk tetap mengembangkan usaha pertanian dan peternakan yang terpadu dan ramah lingkungan.

\section{SARAN}

Teknologi pembuatan silase dan bokashi pupuk kandang yang diimplementasikan di kelompok tani Syalom dan Elsadai, Desa Oebelo, Kecamatan Kupang Tengah, Kabupaten Kupang, Provinsi NTT hendaknya tetap dipertahankan melalui penerapan manajemen pertanian yang baik. Solusi yang disarankan adalah secara rutin melakukan "arisan" pengumpulan feses ternak sapi dan pembuatan bokashi pupuk kandang. Hal tersebut diperlukan sebagai bagian dari upaya memupuk kebersamaan anggota kelompok tani dan berdampak ekonomi terhadap peningkatan kas kelompok tani.

\section{UCAPAN TERIMAKASIH}

Terima kasih disampaikan kepada Direktorat Riset dan Pengabdian masyarakat yang telah mendukung pendanaan kegiatan Ipteks Bagi Masyarakat melalui Pusat Penelitian dan Pengabdian pada Masyarakat Politeknik Pertanian Negeri Kupang.

\section{REFERENSI}

[1] [BPS] Badan Pusat Statistik Kabupaten Kupang. 2018. Kabupaten Kupang dalam Angka. Badan Pusat Statistik. Kupang.

[2] Randu, M. D. S.,Suek, F. S.,dan Lapenangga, T. 2017. Peningkatan Produktivitas Ternak Sapi Potong Melalui Penerapan Teknologi Peternakan di Kelompok Tani Kota Dale - Kelurahan Oesao. Jurnal Pengabdian Masyarakat Peternakan. 2(1):44-53.

[3] Ilham, F., dan Mukhtar, M. 2018. Perbaikan Produktivitas Kambing Kacang Melalui Pelatihan Pembuatan Pakan Silase Bagi Warga di Kecamatan Bone Pantai Kabupaten Bone Bolango. Jurnal ABDIMAS. 10(2):7-15.

[4] Gesriantuti, N., Elsie., Harahap, I., Herlina, N., dan Badrun, Y. 2017. Pemanfaatan Limbah Organik Rumah Tangga dalam Pembuatan Pupuk Bokashi di Kelurahan Tuah Karya, Kecamatan Tampan, Pekanbaru. Jurnal UntukMu NegeRI. 1(1):72-77.

[5] Raksun, A., dan Mertha, I. G. 2018. Pengaruh Bokashi Terhadap Produksi Terong Ungu(Solanum melongena L.). Jurnal Biologi Tropis. 18(1):21-26.

[6]Wantania, D. I., Rumambi, A., dan Kaunang, W. B. 2018. Pemanfaatan Bokashi Feses Sapi Terhadap Produktivitas Ratun Sorgum Varietas Kawali. Jurnal Zootek.38(1):9-16. 